\title{
Strategic priorities for cultivating commitment amongst academic staff: The militating effect of workplace spirituality
}

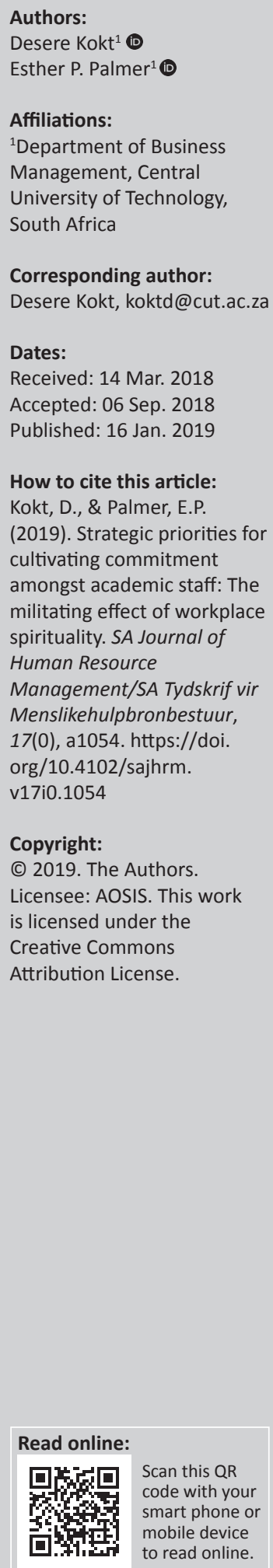

Orientation: Organisational commitment remains an ongoing concern for organisations, especially universities that often struggle to retain academic staff. Universities cannot operate or fulfil their mandate to society without the critical competencies of academic staff.

Research purpose: This investigation focused on workplace spirituality as a militating factor in enhancing the commitment of academic staff.

Motivation for the study: As organisational commitment remains a challenge for universities, this article contributes to a theoretical and empirical understanding of the militating influence of workplace spirituality. The study is underpinned by social learning theory and proposes strategic priorities to universities - informed by an empirical study conducted amongst academic staff members at a South African university.

Research approach/design and method: The study employed a quantitative research approach and a structured questionnaire was administered to 285 academic staff members (ranging from junior lecturers to professors) of a South African university. The research design was a survey and, as a single university formed part of the study, regression analysis was used to establish the relationship between workplace spirituality and organisational commitment.

Main findings: The empirical findings showed a strong linear relationship between workplace spirituality and organisational commitment. A regression formula was developed to statistically calculate the commitment score of individuals.

Practical/managerial implications: The study proposed strategic priorities that may be useful to university management and human resource practitioners to cultivate increased commitment amongst academic staff.

Contribution/value-add: The study contributed empirical evidence of the militating effect of workplace spirituality on organisational commitment, implying that workplace spirituality is a predictor for organisational commitment.

\section{Introduction}

Globalisation and its pervasive influence has led to substantial changes and challenges in organisations. Prominent amongst these are increased digitalisation and virtualisation of the workplace, as well as increased diversity and an emphasis on the skills of employees (Deloitte, 2017). In this sense universities play an important role in supplying business and industry with suitably qualified knowledge workers. Universities are mandated to meet the changing needs of the modern organisation and assist in socio-economic development through appropriate education and training programmes. Universities can only achieve this if they employ competent academic staff in the different disciplines and programmes they offer. It is, however, a concern that universities often struggle to attract and retain academic staff (Lynch, 2014; Selesho, Africa, \& Naile, 2014).

In previous generations universities had a strong collegial ethos and structuring - this was characterised by informal structures and decision-making, long-term relationships and largely unregulated work regimes. This implied that academic staff experienced more autonomy, interdependence and mutual support. In the globalised world this collegial character of universities has evolved into increasing managerialism. Managerialism is characterised by the adaptation of 'private sector tools in public sector organisations' (Lynch, 2015). Managerialism finds meaning in the managerial elements of organising, the rigorous evaluation of work, an 
emphasis on output over input, close monitoring of employee performance and the use of performance indicators and rankings (Lynch, 2014). It can thus be argued that increased managerialism may have severe implications for job satisfaction, morale and the commitment of academic staff.

As contemporary employees have a need to find purpose and meaning in their jobs, the concept of workplace spirituality has gained prominence (see Chawla \& Guda, 2010, 2013; Mohan \& Uys, 2006; Van Tonder \& Ramdass, 2009). It can be argued that a spiritual workplace gives credence to nourishing the inner life of employees, which is essential in enhancing well-being and a sense of belonging amongst employees (Chawla \& Guda, 2013; Fry \& Slocum, 2008; Mohan \& Uys, 2006; Van Tonder \& Ramdass, 2009). Because of diminishing collegialism, as explained above, workplace spirituality may compensate for the challenges associated with managerialism - which is output- and performance-driven. Instilling a spiritual workplace can have positive implications for the talent management practices of universities, which are under continuous pressure to attract and retain highly qualified academic staff.

Although related, workplace spirituality is different from spirituality (the religious processes associated with organised religion) and religion (which is concerned with faith) (Marques, 2006). Despite extensive studies (see Cooper-Hakim \& Viswesvaran, 2005; Mathieu \& Zajac, 1990; Meyer, Stanley, Herscovitch, \& Topolnytsky, 2002; Riketta, 2002) on the predictors and antecedents of organisational commitment, empirical research on the impact of workplace spirituality on organisational commitment in the university context remains scarce. There are, however, some investigations that focus on commitment in the university context (see Churchman, 2006; Fanggida, Rolland, Suryana, Efendi, \& Hilmiana, 2016; Mowday, Porter, \& Steers, 1982), but they are mostly confined to first-world countries with little emphasis on developing countries.

\section{Purpose}

The article proposes that workplace spirituality has a militating effect on organisational commitment. With social learning theory as theoretical framework and considering the findings of an empirical study conducted at a South African university, the article proposes strategic priorities to enhance the organisational commitment of academic staff.

\section{Literature review}

\section{Organisational commitment}

The concept of 'organisational commitment' has evolved since the 1960s to include some consensus that it implies the willingness of employees to exert more effort in performing their jobs, displaying a strong desire to stay with an organisation and an inclination to subscribe to the major goals and values of an organisation (Alderfer, Porter, \& Lawler, 1968). In later definitions the psychological dimension of organisational commitment emerges (see Meyer, Allen, \&
Gellatly, 1990; McMahon, 2007) and it is explained in terms of the dynamic psychological state that is constructed by an employee based on the experiences of the employee in the work situation. There is extensive empirical evidence that attests to the advantages of a strongly committed workforce (Ahiauzu \& Asawo, 2009; Meyer \& Maltin, 2010; Morrow, 2011; Nehmeh, 2009; Rego \& Pina e Cunha, 2008; Wainaina, Iravo, \& Waititu, 2014) and consensus that committed employees are more likely to attend work regularly, perform effectively and be good organisational citizens.

This article adopted the three-component model (TCM) of Meyer and Allen (2004) as a means of investigating organisational commitment in the university context. The TCM Employee Commitment Survey has been confirmed as a rigorous measure of organisational commitment (Meyer, Stanley, \& Parfyonova, 2012; Wasti, 2005). According to the TCM, organisational commitment comprises affective, normative and continuance commitment. Affective commitment refers to commitment based on the emotional ties the employee develops with the organisation, normative commitment reflects commitment based on the perceived obligation towards an organisation, rooted in the norms of reciprocity, and continuance commitment involves commitment based on the perceived costs, both economically and socially, of leaving the organisation. Commitment is thus viewed as a psychological state that (1) characterises the employee-organisation relationship and (2) influences the decision to continue or discontinue membership with the organisation (Wasti, 2005).

Because of its applicability, Bandura's social learning theory serves as the theoretical framework for this study (Bandura, 1971). Social learning theory postulates that learning is a social phenomenon driven by the human capacity to continuously learn by observing the behaviour of others. This can elicit emotional responses, both positive and negative, depending on the affective reactions of those setting the example. This links directly to organisational commitment, specifically affective commitment, which refers to the emotional attachments employees are likely to form with an organisation, thus supporting the applicability of the theory (Rego \& Pina e Cunha, 2008).

\section{Workplace spirituality}

As indicated before, contemporary employees have a greater need to be engaged in their work and to make a meaningful contribution to the organisation (Chawla \& Guda, 2013; Fry \& Slocum, 2008; Van Tonder \& Ramdass, 2009). 'Workplace spirituality' relates the desires of employees to live integrated, holistic lives, including recognition and acceptance of their spirituality in the work context (Aravamudhan \& Khrishmaveni, 2014). By analysing literature (see BinBakr \& Ahmed, 2015; Mohamed \& Ruth, 2016; Wainaina et al., 2014) three distinct components of workplace spirituality emerge sense of meaning, sense of purpose and a sense of community or connectedness with others. For the sake of this study, workplace spirituality can be explained as a dynamic process 
through which individuals express personal values within the organisational context in search of a greater sense of meaning and purpose through their connectedness and community with others. When employees experience meaning and purpose in their work they are more likely to experience higher levels of self-esteem and are less likely to become alienated and detached from their work.

A sense of community or connectedness is likely to lead to the awakening of an inner sense (spirituality), which can be viewed as a metaphysical part of humans and the work they perform - an awareness of something beyond the world as we know it. According to Ashforth and Pratt (2003) this 'something' can include other people, a cause, nature or a belief in a higher power. The findings of numerous studies (see Benefiel, 2003; Biberman \& Whitty, 1997; Brown, 2003; Delbecq, 1999; Eisler \& Montouori, 2003; Fry, 2003; Giacalone \&Jurkiewicz, 2003; Kinjerski \&Skrypnek, 2004; Krishnakumar \& Neck, 2002; Leigh, 1997; Wagner-Marsh \& Conely, 1999) postulate that workplace spirituality has a positive relationship with the following variables: honesty and trust, kindness and fairness, creativity, increased profits, morale, organisation performance and development, productivity and reduced absenteeism and turnover.

\section{Method}

\section{Research approach}

The ontological position of the study adheres to objectivism, as the researchers believe that reality lies outside the subjective experiences of respondents. This aligns with the epistemological stance of positivism that entails obtaining objective knowledge through deductive or theory testing approaches. From an organisational perspective, positivism supports the notion that an organisation, as a society, can be viewed as an existing entity or social substructure that can be objectively studied (Jakobsen, 2013). Positivism was, therefore, regarded as an appropriate paradigm for this study. It further allows for results to be replicated by other researchers. Considering the aim of the study and the relatively large population, a quantitative research approach was thus adopted (Robson \& McCartan, 2015).

\section{Measures}

The data was gathered using a structured questionnaire, and Cronbach's alpha was applied to verify the internal consistency of the questionnaire. An alpha score above 0.75 is generally accepted as an indication of high reliability, while a score between 0.50 and 0.75 indicates moderate reliability. Cronbach's alpha was calculated for both the workplace spirituality and organisational commitment sections of the questionnaire. An alpha value of 0.95 was recorded for the workplace spirituality section, confirming excellent reliability. For the organisational commitment section an alpha score of 0.53 was recorded. The lower alpha score is because of the diverse measurement items (affective, normative and continuance commitment) and the smaller number of items. However, this section of the questionnaire can still be regarded as reliable.

\section{Participants}

A structured questionnaire was administered to 285 academic staff members (ranging from junior lecturers to professors) at a South African university. QuestionPro was used to administer the questionnaire and a link to the questionnaire was emailed to the respondents. As indicated before, all academic staff members of the university were targeted. The necessary permission was obtained from the university to conduct the investigation. In total, 174 respondents successfully completed the questionnaire yielding a response rate of $61 \%$.

\section{Measuring instrument}

The questionnaire was structured and consisted of two sections: Section A captured workplace spirituality and Section B organisational commitment. Section A integrated the following survey instruments - spirit at work (based on Kinjerski \& Skrypnek, 2004), spiritual perspectives (based on Reed, 1986), finding meaning and purpose at work (Duchon \& Plowman, 2005), as well as the organisational spiritual values instrument of Kolodinsky, Giacalone and Jurkiewicz (2008). Section B was based on the TCM of Meyer and Allen (2004) that measured affective, normative and continuance commitment.

\section{Design}

The study followed a survey research design and a single South African university formed part of the study.

\section{Analysis}

Both descriptive and inferential statistics were performed on the data and regression analysis was used to establish whether there was a relationship between workplace spirituality and organisational commitment.

\section{Results}

The following section reports the results of the empirical study. Table 1 provides a synopsis of the workplace spirituality scores. The scores were captured on a six-point Likert scale with the following values: 1 (strongly disagree), 2 (disagree), 3 (slightly disagree), 4 (slightly agree), 5 (agree) and 6 (strongly agree).

It is evident from Table 1 that most of the average means scores reflect 'agree' and 'strongly agree' responses, meaning most of the items had positive responses.

The average scores for the different dimensions of workplace spirituality (namely, sense of meaning, sense of purpose and sense of community) were also calculated. They are reflected in Table 2.

The items depicting sense of meaning accounted for the highest contribution (79\%) to workplace spirituality, followed by sense of purpose $(77 \%)$. Sense of community yielded the lowest score. The average workplace spirituality score for academic staff members was $76 \%$. 
TABLE 1: Descriptive statistics for workplace spirituality.

\begin{tabular}{|c|c|c|c|c|c|c|c|}
\hline No. & Description & Average mean score & Valid $n$ & Median & Mode & Minimum & Maximum \\
\hline 1.1 & I feel part of the university community. & 4 & 173 & 5 & 5. & 1 & 6 \\
\hline 1.2 & Departmental members have integrity. & 5 & 174 & 5 & 5. & 1 & 6 \\
\hline 1.3 & My job contributes to my personal growth. & 5 & 174 & 5 & 5. & 2 & 6 \\
\hline 1.4 & My work has personal meaning. & 5 & 174 & 5 & 5. & 2 & 6 \\
\hline 1.5 & I am encouraged to participate freely in my department. & 5 & 174 & 5 & 5. & 1 & 6 \\
\hline 1.6 & In my department we resolve conflict constructively. & 4 & 173 & 5 & 5. & 1 & 6 \\
\hline 1.7 & I feel I belong at the university. & 5 & 171 & 5 & 5. & 1 & 6 \\
\hline 1.8 & I am encouraged to express my ideas and opinions freely. & 4 & 171 & 5 & 5. & 1 & 6 \\
\hline 1.9 & My organisation cares about whether I am motivated by my work. & 4 & 173 & 4 & Multiple & 1 & 6 \\
\hline 1.10 & I feel energised by my work. & 5 & 172 & 5 & 5. & 1 & 6 \\
\hline 1.11 & I find it easy to develop new skills and abilities at work. & 5 & 174 & 5 & 5. & 1 & 6 \\
\hline 1.12 & I am helpful to others. & 5 & 174 & 5 & 5. & 2 & 6 \\
\hline 1.13 & My organisation recognises my responsibilities to my family. & 4 & 173 & 5 & 5. & 1 & 6 \\
\hline 1.14 & My department cares about the health of its members. & 4 & 174 & 4 & 5. & 1 & 6 \\
\hline 1.15 & I can discuss my fears at work. & 4 & 171 & 4 & 5. & 1 & 6 \\
\hline 1.16 & I enjoy my work. & 5 & 173 & 5 & 5. & 1 & 6 \\
\hline 1.17 & I am confident to express myself honestly at work. & 4 & 173 & 5 & 5. & 1 & 6 \\
\hline 1.18 & My line manager encourages my personal growth. & 5 & 174 & 5 & 5. & 1 & 6 \\
\hline 1.19 & My work is meaningful. & 5 & 172 & 5 & 5. & 1 & 6 \\
\hline 1.20 & My organisation cares about its employees. & 4 & 173 & 4 & 5. & 1 & 6 \\
\hline 1.21 & My work contributes to the social good of my community. & 5 & 172 & 5 & 5. & 1 & 6 \\
\hline 1.22 & I agree with the values of the university. & 5 & 173 & 5 & 5. & 1 & 6 \\
\hline 1.23 & I do my job automatically. $\dagger$ & 2 & 171 & 2 & 2. & 1 & 6 \\
\hline 1.24 & I agree with the goals of my department. & 5 & 172 & 5 & 5. & 2 & 6 \\
\hline 1.25 & I am encouraged to use my knowledge and experience at work. & 5 & 172 & 5 & 5. & 1 & 6 \\
\hline 1.26 & I can take any concern I have at work to my line manager. & 4 & 171 & 5 & 5. & 1 & 6 \\
\hline 1.27 & I feel positive about my future with my department. & 4 & 173 & 5 & 5. & 1 & 6 \\
\hline 1.28 & I hope to influence others with my positive attitude. & 5 & 172 & 5 & 5. & 3 & 6 \\
\hline 1.29 & My performance is evaluated fairly. & 4 & 173 & 4 & 5. & 1 & 6 \\
\hline 1.30 & I am willing to make sacrifices for colleagues. & 5 & 170 & 5 & 5. & 1 & 6 \\
\hline 1.31 & People in my department are not encouraged to learn and grow. & 5 & 173 & 5 & 5. & 1 & 6 \\
\hline 1.32 & I experience a real sense of personal connection with colleagues. & 4 & 173 & 4 & 5. & 1 & 6 \\
\hline 1.33 & I feel enthusiastic about my work. & 5 & 173 & 5 & 5. & 1 & 6 \\
\hline 1.34 & I feel valued at work. & 4 & 173 & 5 & 5. & 1 & 6 \\
\hline 1.35 & I look forward to coming to work most of the time. & 5 & 173 & 5 & 5. & 1 & 6 \\
\hline 1.36 & I do not care about my colleagues' problems. & 5 & 172 & 5 & 5. & 1 & 6 \\
\hline
\end{tabular}

$\dagger$, These questions have been rescaled and should be interpreted in reverse.

TABLE 2: Average scores for workplace spirituality dimensions.

\begin{tabular}{lcc}
\hline Dimension & Average score & Percentage \\
\hline Sense of meaning & 4.74 & 79 \\
Sense of purpose & 4.60 & 77 \\
Sense of community & 4.37 & 73 \\
\hline Total score & 4.51 & 76 \\
\hline
\end{tabular}

Table 3 reports the organisational commitment scores. The responses were captured on a five-point Likert scale (1- strongly disagree, 2 - disagree, 3 - neither disagree nor agree, 4 - agree, 5 - strongly agree).

Table 3 shows that the average mean scores of the organisational commitment section vary between 3 and 4 . Table 4 displays the organisational commitment dimensions (affective, normative and continuance commitment).

Table 4 shows that an average organisational commitment score of $61 \%$ was recorded. Affective commitment received the highest score of $60 \%$ and continuance commitment the lowest (58\%).

\section{Regression analyses}

Regression analysis was performed to determine whether there is a relationship between workplace spirituality (independent variable) and organisational commitment (dependant variable). The scatter plot in Figure 1 indicates the findings.

Figure 1 shows an upward sloping relationship, which indicates that there is a strong positive linear relationship between workplace spirituality and organisational commitment.

Table 5 highlights the results of the regression analysis, illustrating the dependence of organisational commitment on the employees' perception of workplace spirituality. The regression analysis showed a relationship of $R=0.434$ and $R^{2}=0.19$. This indicates that $19 \%$ of the variation in organisational commitment could be explained by workplace spirituality. The remaining $81 \%$ is explained by other variables.

The regression analysis confirms that there is a linear relationship between workplace spirituality and 
TABLE 3: Descriptive statistics for organisational commitment.

\begin{tabular}{|c|c|c|c|c|c|c|c|}
\hline No. & Description & Average mean score & Valid $n$ & Median & Mode & Minimum & Maximum \\
\hline 3.1 & The university contributes to a sense of personal meaning. & 4 & 171 & 4 & 4. & 1 & 5 \\
\hline 3.2 & Staying with the university is a matter of necessity to me. & 3 & 170 & 4 & 4. & 1 & 5 \\
\hline 3.3 & I owe a great deal to the university. & 3 & 173 & 4 & 4. & 1 & 5 \\
\hline 3.4 & I see myself working at the university for a long time. & 4 & 172 & 4 & 4. & 1 & 5 \\
\hline 3.5 & I feel that I have too few other options to leave the university. & 3 & 170 & 3 & 4. & 1 & 5 \\
\hline 3.6 & I do not feel 'emotionally attached' to my organisation. & 3 & 172 & 2 & 2. & 1 & 5 \\
\hline 3.8 & I really feel as if the university's problems are my own. & 3 & 173 & 3 & 4. & 1 & 5 \\
\hline 3.9 & I feel like I am part of the university family. & 3 & 174 & 4 & 4. & 1 & 5 \\
\hline 3.10 & My sense of obligation to my colleagues keeps me at the university. & 3 & 174 & 3 & 3. & 1 & 5 \\
\hline 3.11 & I do not feel a strong sense of 'belonging' to my organisation. & 3 & 173 & 2 & 2. & 1 & 5 \\
\hline 3.12 & The university deserves my loyalty. & 4 & 174 & 4 & 4. & 1 & 5 \\
\hline 3.13 & My life would be disrupted if I left the university now. & 3 & 174 & 3 & 2. & 1 & 5 \\
\hline 3.14 & I am strongly considering finding other employment. & 3 & 174 & 2 & 2. & 1 & 5 \\
\hline
\end{tabular}

TABLE 4: Organisational commitment dimensions.

\begin{tabular}{lcc}
\hline Dimension & Average score & Percentage \\
\hline Affective commitment & 2.98 & 60 \\
Normative commitment & 3.32 & 66 \\
Continuance commitment & 2.92 & 58 \\
\hline Total score & $\mathbf{3 . 0 7}$ & $\mathbf{6 1}$ \\
\hline
\end{tabular}

TABLE 5: Regression analysis for workplace spirituality and organisational commitment.

\begin{tabular}{lcccc}
\hline Variable & \multicolumn{4}{c}{ Organisational commitment } \\
\cline { 2 - 5 } & $\boldsymbol{B}$ & $\mathrm{SE}$ & $\boldsymbol{T ( 1 7 2 )}$ & $\boldsymbol{p}$ \\
\hline Intercept & 26.204 & 2.618 & 10.008 & 0 \\
Workplace spirituality & 0.101 & 0.015 & 6.327 & 0 \\
\hline
\end{tabular}

Note: $N, 174 ; R, 0.43 ; R^{2}, 0.19$; adjusted $R^{2}, 0.18408915 ; F(1,172), 40.033 ; p, p$-value $<0.00$; $\mathrm{SE}$, estimate 5.4348 .

$\mathrm{SE}$, standard error; $B$, co-efficient; $T$, degrees of freedom

organisational commitment. Workplace spirituality can therefore be regarded as a predictor of organisational commitment. Table 3 also shows that the $p$-value for the $F$-test of overall significance is $p<0.00$, which is less than the specified 0.05 . This provides support for the statistical significance of the regression model. The following regression equation is derived from the preceding results and could be useful for future research:

Organisational Commitment (OC) score $=26.2+(0.101 \times$ Workplace Spirituality (WS) score)

[Eqn 1]

\section{Discussion}

\section{Outline of the results}

Regarding overall workplace spirituality, Table 2 shows that the average scores for sense of meaning and sense of purpose were higher than those for sense of community. The overall WS score was $76 \%$. Table 3 shows that normative commitment received the highest average score, followed by affective commitment and then continuance commitment. This implies that academics feel some obligation to stay with the university and that they have emotional ties with the university. Respondents scored lowest on the continuance commitment dimension, which pertains to the economic and social cost of leaving the university.

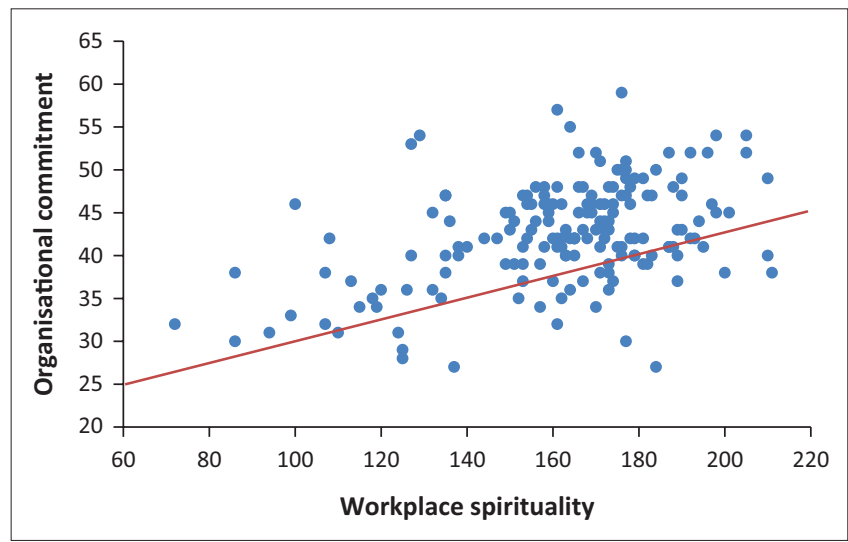

Note: Organisational commitment vs workplace spirituality $-Y=26.2+0.101 \times$ WS

FIGURE 1: Regression line of workplace spirituality versus organisational commitment. Y, organisational commitment; WS, workplace spirituality.

This correlates with the findings of BinBakr and Ahmed (2015) amongst faculty members in Saudi Arabia, where the affective commitment was $85 \%$, the normative commitment score $73 \%$ and the continuance commitment 52\%. Other studies (see Gutierrez, Candela, \& Carver, 2012; Rego \& Pina e Cunha, 2008) also show a tendency for continuance commitment to score the lowest.

Mohamed and Ruth (2016) found that meaningful work positively affects continuance commitment amongst public school teachers in Egypt. Other studies (see Chawla \& Guda, 2010; Javanmard, 2012; Osman-Gani, Hashim, \& Ismail, 2013) also found that sense of meaning and sense of purpose were associated with the affective and normative commitment of employees. Milliman, Czaplewski and Ferguson (2003) found that workplace spirituality also explained positive work attitudes such as organisational commitment and intentions to leave, emphasising that meaningful work reduces the likelihood of quitting. According to Mohamed and Ruth (2016) spirituality in the workplace is important for creating a healthy work environment where employees feel valued and where they purposefully contribute to the success of the organisation.

The regression analysis indicated that there was a positive linear relationship between workplace spirituality and organisational commitment. It can thus be concluded that 
WS is a statistically significant predictor of employee commitment, as $19 \%$ of the variation in OC was explained by WS. Irrespective of the established linear relationship between workplace spirituality and organisational commitment, it is valuable to note that the average OC score $(60 \%)$ of academic staff at the university was lower than the average WS score $(71 \%)$. This may be attributed to increased managerialism in the university, which may lead to lower levels of OC amongst academic staff (Lynch, 2015). The higher workplace spirituality average, however, does suggest that academic staff at the university find some meaning, purpose and sense of community in what they do.

\section{Practical implications}

The practical implications of the study lie on a strategic level as top management needs to initiate actions that could contribute to the development of a spiritual workplace. Top management and academic leaders should support and create spaces for WS to prosper and for academic staff to find purpose and meaning in their careers. Positive employer-employee engagement and open communication is likely to support WS and increase the commitment levels of academic staff. Spiritual values should also be incorporated into organisational development (such as seminars and workshops) and change processes (such as instilling and supporting spiritual values).

\section{Limitations and recommendations}

A major limitation of this study is that the empirical study was only conducted at one university. It is therefore not possible to generalise the findings to other universities. The findings, however, provide some indication of the militating effect of WS on organisational commitment.

Based on the premise that human beings are part of social structures and that they learn through observation and interaction, as encapsulated by social learning theory, as well as the findings of the empirical investigation, the following strategic priorities are proposed to universities:

- Policy frameworks and governance: The institutional human resource departments, in collaboration with academic leaders, should develop policies that encourage and support commitment through workplace spirituality principles. Spiritual values like honesty, trust, humility, compassion and service should be enabled by the culture of the university and new academic staff members should be recruited based on their ability to align themselves with these values.

- Organisational culture: An enabling organisational culture is not possible if leaders at the top do not set the example. No organisation can prosper without strong, ethical leaders that set clear and achievable goals to subordinates. An enabling organisational culture and strong leadership thus precedes organisational commitment and for that matter variables such as WS. It is suggested that academic leadership should draw from the lessons of Covey's principle-centred leadership. This involves personal trustworthiness, interpersonal trust, managerial empowerment and organisational alignment, which are likely to create spiritually centred leaders. If leaders are perceived as credible, increased levels of commitment are likely to result (Covey \& Gulledge, 1992).

- Instilling spiritual values: It is further recommended that continuous professional development of academic staff should not only be regarded or evaluated from a financial point of view but also viewed in terms of the spiritual growth it provides to create increased meaning and purpose in the work they do.

- Creating platforms for enhanced workplace spirituality: Mechanisms should be put in place to help academic staff experience a connection between their individual vision, mission and values and those of the university to improve commitment levels. Platforms like intrapersonal interventions (i.e. self-reflection, exploring the job as a calling; introducing quality circles, etc.), interpersonal interventions (i.e. employee development programmes focusing on human values and work-life balance) and group interventions (i.e. spiritual team-building exercises, spiritual leadership development) should be created to stimulate organisational learning.

- Measuring the commitment levels of future employees: The selection process for academic staff members should incorporate measurement of the potential organisational commitment level of incumbents, using the measure of the Organisational Commitment (OC) score $=26.2+$ $0.101 \times$ Workplace Spirituality (WS) score) as derived from this study. This could form part of psychological testing during selection to determine future commitment levels to the university.

- Commitment measuring as a management tool: Academic leaders can also use the preceding equation as a managerial tool to add information to an existing employee's level of commitment to the university. This could contribute to establishing an organisational culture that would be conducive to increased workplace spirituality and subsequently to increased retention and commitment.

- Performance management that incorporates the spiritual dimensions: From a performance management perspective, it is imperative that academic staff members be equally appraised on their 'existence/being' and behaviour as on their productivity and outputs. The performance management system should incorporate values that will help academic staff members believe that their activities have meaning beyond the economic benefits for the university or self-gratification.

- Studies of a similar nature should be conducted at universities: Given the infancy of studies pertaining to the impact of workplace spirituality on organisational commitment at universities in South Africa, further empirical research in the field can lead to more generalisable findings.

\section{Conclusion}

The aim of this article was to address the continuous challenge of OC by theoretically and empirically investigating the militating effect of WS. The main finding showed a positive linear relationship between workplace spirituality and organisational commitment, which led to proposing 
strategic priorities of value for academic managers and human resource practitioners alike.

\section{Acknowledgements Competing interests}

The authors declare that they have no financial or personal relationships that may have inappropriately influenced them in writing this article.

\section{Authors' contributions}

D.K. conceptualised and wrote the article. E.P.P. assisted with the literature review and performed data collection for the study.

\section{References}

Ahiauzu, A., \&Asawo, S. (2009). Unwavering hope and workers' commitment in the Nigerian manufacturing industry: A study in workplace spirituality. Business Renaissance Quarterly, 4(1), 105-124. Retrieved from http://fw8pk7vf4q.search.serialssolutions. com/?ctx ver=Z39.88-2004\&ctx enc=info:ofi/enc:UTF-8\&rfr id=info:sid/ com/?ctx_ver=Z39.88-2004\&ctx_enc=info:ofi/enc:UTF-8\&rfr_id=info:sid/
ProQ\%3Aabiglobal\&rft val fmt=info:ofi/fmt:kev:mtx:journal\&rft.genre=article\&rft. ProQ\%3Aabiglobal\&rft_val_fmt=info:ofi/fmt:kev:mtx:journal\&rft.gen
jtitle=Business+Renaissance+Quarterly\&rft.atitle=Unwavering+Hope+

Alderfer, C. P., Porter, L. W., \& Lawler, E. E. (1968). Managerial attitudes and performance. Administrative Science Quarterly, 13(1), 177. https://doi.org/10.2307/2391269

Aravamudhan, N. R., \& Khrishmaveni, R. (2014). Spirituality at work place - An emerging template for organization capacity building? Purushartha, 7(1), 63-78.

Ashforth, B. E., \& Pratt, M. G. (2003). Institutionalized spirituality: An oxymoron? In C. Giacalone \& R. A. Jurkiewicz (Eds.), Handbook of workplace spirituality and organizational performance, (pp. 93-107). New York, NJ: ME Sharpe.

Bandura, A. (1971). Social Learning Theory. New York: General Learning Press. https:// doi.org/10.1111/j.1460-2466.1978.tb01621.x

Benefiel, M. (2003). Irreconcilable foes? The discourse of spirituality and the discourse of organizational science. SAGE Journals, 10(2), 383-391. https://doi. org/10.1177/1350508403010002012

Biberman, J., \& Whitty, M. (1997). A postmodern spiritual future for work Journal of Organizational Change Management, 10(2), 130-138. https://doi. org/10.1108/09534819710160790

BinBakr, M. B., \& Ahmed, E. I. (2015). An empirical investigation of faculty members' organizational commitment in the Kingdom of Saudi Arabia. American Journal of
Educational Research, 3(8), 1020-1026. https://doi.org/10.12691/education-3-8-12

Brown, R. B. (2003). Organizational spirituality: The sceptic's version. SAGE Journals, 10(2), 393-400. https://doi.org/10.1177/1350508403010002013

Chawla, V., \& Guda, S. (2010). Individual spirituality at work and its relationship with job satisfaction, propensity to leave and job commitment: An exploratory study among sales professionals. Journal of Human Values, 16(2), 157-167. https://doi. org/10.1177/097168581001600203

Chawla, V., \& Guda, S. (2013). Workplace spirituality as a precursor to relationship oriented selling characteristics. Journal of Business Ethics, 115(1), 63-73. https:// doi.org/10.1007/s10551-012-1370-y

Churchman, D. (2006). Institutional commitments, individual compromises: Identity-related responses to compromise in an Australian university. Journa of Higher Education Policy and Management, 28(1), 3-15. https://doi org $/ 10.1080 / 13600800500283676$

Cooper-Hakim, A., \& Viswesvaran, C. (2005). The construct of work commitment: Testing an integrative framework. Psychological Bulletin, 131(2), 241-259. https:// doi.org/10.1037/0033-2909.131.2.241

Covey, S. R., \& Gulledge, K. (1992). Principle-centered leadership. The Journal for Quality and Participation, 15(4), 70. https://doi.org/10.1108/17506200710779521

Delbecq, L. A. (1999). Christian spirituality and contemporary business leadership. Journal of Organizational Business Management, 12(4), 345-349.

Deloitte. (2017). 2017 Deloitte Global Human Capital Trends. Retrieved from https:// www2.deloitte.com/content/dam/Deloitte/global/Documents/About-Deloitte/ central-europe/ce-

Duchon, D., \& Plowman, D. A. (2005). Nurturing the spirit at work: Impact on work unit performance. Retrieved from http://digitalcommons.unl.edu/managementfacpub/65

Eisler, R., \& Montouori, A. (2003). The human side of spirituality. In C. L. Giacalone \& R. A. Jurkiewicz (Eds.), Handbook of workplace spirituality and organizational performance (pp. 46-56). New York: Armorok.

Fanggida, E., Rolland, E., Suryana, Y., Efendi, N., \& Hilmiana. (2016). Effect of a spirituality workplace on organizational commitment and job satisfaction. (Study on the Lecturer of Private Universities in the Kupang City -Indonesia). Procedia-Social and Behavioral Sciences, 219, 639-646. https://doi.org/10.1016/j.sbspro.2016.05.045

Fry, L. W. (2003). Toward a theory of spiritual leadership. Leadership Quarterly, 14(6), 693-727. https://doi.org/10.1016/j.leaqua.2003.09.001
Fry, L. W., \& Slocum, J. W. (2008). Maximizing the triple bottom line through spiritual leadership. Organizational Dynamics, 37(1), 86-96. https://doi.org/10.1016/j. orgdyn.2007.11.004

Giacalone, R. A., \& Jurkiewicz, C. (2003). Toward a science of workplace spirituality. In C. L. Giacalone, and R. A. Jurkiewicz (Eds.), Handbook of workplace spirituality and organizational performance (pp. 3-28). New York: Armonk.

Gutierrez, A. P., Candela, L. L., \& Carver, L. (2012). The structural relationships between organizational commitment, global job satisfaction, developmental experiences, work values, organizational support, and person-organization fit among nursing faculty. Journal of Advanced Nursing, 68(7), 1601-1614. https://doi.org/10.1111/ j.1365-2648.2012.05990.x

Jakobsen, T. G. (2013). Theory of science: What is positivism. Popular social science. Retrieved from http://www.popularsocialscience.com/2013/02/15/theory-ofscience-what-is-positivism/6/12/2016

Javanmard, H. (2012). The impact of spirituality on work performance. The Indian Journal of Science and Technology, 5(1), 113-145.

Kinjerski, V. M., \& Skrypnek, B. J. (2004). Defining spirit at work: Finding common ground. Journal of Organizational Change Management, 17(1), 26-42. https:// doi.org/10.1108/09534810410511288

Kolodinsky, R. W., Giacalone, R. A., \& Jurkiewicz, C. L. (2008). Workplace values and outcomes: Exploring personal, organizational, and interactive workplace spirituality. Journal of Business Ethics, 81(2), 465-480. https://doi.org/10.1007/ s10551-007-9507-0

Krishnakumar, S., \& Neck, C. P. (2002). The "what", "why" and "how" of spirituality in the workplace. Journal of Managerial Psychology, 17(3), 153-164. https://doi. org/10.1108/02683940210423060

Leigh, P. (1997). The new spirit at work. Training \& Development, 51, 26-33.

Lynch, K. (2014). New managerialism: The impact on education. Concept, 5(3), $1-11$.

Lynch, K. (2015). Control by numbers: New managerialism and ranking in higher education. Critical Studies in Education, 56(2), 190-207. https://doi.org/10.108 0/17508487.2014.949811

Marques, J. F. (2006). The spiritual worker: An examination of the ripple effect that enhances quality of life in- and outside the work environment. Journal of Management Development, 25(9), 884-895. https://doi.org/10.1108/02621710 610692089

Mathieu, J. E., \& Zajac, D. M. (1990). A review and meta-analysis of the antecedents, correlates, and consequences of organizational commitment. Psychological Bulletin, 108(2), 171-194. https://doi.org/10.1037/0033-2909.108.2.171

McMahon, B. (2007). Organizational commitment, relationship commitment and their association with attachment style and locus of control. Georgia Institute of Technology. Retrieved from http://www.livingdementia.com/downloads/ newsletters/2011/jul_aug/organization_relationship_locus_of_control.pdf

Meyer, J. P., \& Allen, N. J. (2004). TCM employee commitment survey academic users guide 2004. Retrieved from http://employeecommitment.com/TCM-EmployeeCommitment-Survey-Academic-Package-2004.pdf

Meyer, J. P., Allen, N. J., \& Gellatly, I. R. (1990). Affective and continuance commitment to the organization: Evaluation of measures and analysis of concurrent and timelagged relations. Journal of Applied Psychology, 75(6), 710-720. https://doi. org/10.1037/0021-9010.75.6.710

Meyer, J. P., \& Maltin, E. R. (2010). Employee commitment and well-being: A critica review, theoretical framework and research agenda. Journal of Vocational review, theoretical framework and research agenda. Journal of
Behavior, 77(2), 323-337. https://doi.org/10.1016/j.jvb.2010.04.007

Meyer, J. P., Stanley, D. J., Herscovitch, L., \& Topolnytsky, L. (2002). Affective, continuance, and normative commitment to the organization: A meta-analysis of antecendents, correlates and consequences. Journal of Vocational Behaviour, 61(1), 20-52. https://doi.org/10.1006/jvbe.2001.1842

Meyer, J. P., Stanley, L. J., \& Parfyonova, N. M. (2012). Employee commitment in context: The nature and implication of commitment profiles. Journal of Vocational Behavior, 80(1), 1-16. https://doi.org/10.1016/j.jvb.2011.07.002

Milliman, J., Czaplewski, A. J., \& Ferguson, J. (2003). Workplace spirituality and employee work attitudes: An exploratory empirical assessment. Journal of Organizational Change Management, 16(4), 426-447. https://doi. org/10.1108/09534810310484172

Mohamed, M., \& Ruth, A. (2016). Workplace spirituality and organizational commitment: A study on the public schools teachers in Menoufia (Egypt). African Journal of Business Management, 10(10), 247-255. https://doi.org/10.5897/ AJBM2016.8031

Mohan, D. L., \& Uys, K. (2006). Towards living with meaning and purpose: Spiritual perspectives of people at work. SA Journal of Industrial Psychology, 32(1), 53-59. https://doi.org/10.4102/sajip.v32i1.228

Morrow, P. C. (2011), Managing organizational commitment: Insights from longitudinal research. Journal of Vocational Behaviour, 79, 18-35.

Mowday, R., Porter, L., \& Steers, R. (1982). Employee organization linkages. In P. Warr (Ed.), Organizational and pccupational psychology (pp. 219-229). New York: Academic Press.

Nehmeh, R. (2009). What is organizational commitment, why should managers what it in their workforce and is there any cost-effective way to secure it? Retrieved it in their workforce and is there any cost-effective way to secure it? Retrieved
from https://www.smcuniversity.com/working papers/Ranya Nehmeh - What from https://www.smcuniversity.com/working_papers/Ranya_Nehmeh_-_What is_Organizational_commitment,_why_should_managers_want_it_in_their_
workforce_and_is_there_any_cost_effective_way_to_secure_it.pdf

Osman-Gani, A. M., Hashim, J., \& Ismail, Y. (2013). Establishing linkages between religiosity and spirituality on employee performance. Employee Relations, 35(4), 360-376. https://doi.org/10.1108/ER-04-2012-0030 
Reed, P. G. (1986). Religiousness among terminally ill and healthy adults. Research in Nursing and Health, 9(1), 35-41. https://doi.org/10.1002/nur.4770090107

Rego, A., \& Pina e Cunha, M. (2008). Workplace spirituality and organizational commitment: An empirical study. Journal of Organizational Change Management, 21(1), 53-75. https://doi.org/10.1108/09534810810847039

Riketta, M. (2002). Attitudinal organizational commitment and job performance: A meta-analysis. Journal of Organizational Behavior, 23(3), 257-266. https://doi org/10.1002/job.141

Robson, C., \& McCartan, K. (2015). Real world research: A resource for users of social science research methods in applied settings. London: Wiley and Sons.

Selesho, J. M., Africa, S., \& Naile, I. (2014). Academic staff retention as a human resource factor: University perspective. International Business \& Economics Research Journal, 13(2), 295-305.
Van Tonder, C. L., \& Ramdass, P. (2009). A spirited workplace: Employee perspectives on the meaning of workplace spirituality. SA Journal of Human Resource Management, 7(1), 230-242. https://doi.org/10.4102/sajhrm.v7i1.207

Wagner-Marsh, F., \& Conely, J. (1999). The fourth wave: The spiritually based firm. Journal of Organizational Change Management, 12(4), 292-301. https://doi. org/10.1108/09534819910282135

Wainaina, L., Iravo, M., \& Waititu, A. (2014). Effect of employee participation in decision making on the organizational commitment amongst academic staff in the private and public universities in Kenya. International Journal of Advanced Research in Management and Social Sciences, 3(12), 131-142.

Wasti, S. A. (2005). Commitment profiles: Combinations of organizational commitment forms and job outcomes. Journal of Vocational Behavior, 67(2), 290-308. https:// doi.org/10.1016/j.jvb.2004.07.002 